$2021,22(2)$, pp. 148-159, DOI : 10.18038/estubtda. 811503

RESEARCH ARTICLE

\title{
MODELING OF URBAN FLOODING AND WATERFALL EFFECT ON STEPPED STREETS IN ISTANBUL, TURKEY
}

\author{
Oğuzhan Murat HALAT ${ }^{1, *(i) ~, ~ I ̇ l k e ~ C I ̇ R I T T C i ~}{ }^{2}$ (iD , Gül YÜCEL ${ }^{2}$ (iD) \\ ${ }^{1}$ Civil Engineering Department, Engineering\&Art Faculty, İstanbul Gelisim University, Istanbul, Turkey \\ ${ }^{2}$ Architectural Department, Engineering\&Art Faculty, İstanbul Gelisim University, Istanbul, Turkey
}

\begin{abstract}
Flood is one of the most common and deadly natural disasters. Most of the cities are under the threat of flash floods due to precipitation regime changes with global climate change. The existing infrastructure and the stepped streets that were not previously risky in the city create a waterfall effect in heavy rain and reduce street safety. Today, there are more than a hundred stepped streets in the settlement as by topography conditions such as Beyoğlu, Şişli and Üsküdar, with different type of stepped streets that form a short path in the transportation network in Istanbul, Turkey. Many researchers studied to calculate discharges through spillways or dam break flows using numerical models. In the study, different step streets related vertically with Meclisi Mebusan Street in Istanbul are examined in terms of flooding after heavy rains. The data is obtained through on-site observation. Physical properties such as stair length, width, slope, stair shape and railing are taken into consideration during the on-site examination. The step street as staircase models was analyzed with FLOW 3D software according to the selected flood height. In the numerical models examined by CFD method, the maximum speed zones occurring on the staircase during the flood were determined and the critical zones were specified. In this way, it is possible to comment on the impact assessment of stairs by considering water heights and speeds in critical areas. According to study results, some preventive measures on stepped streets are suggested for flash floods.
\end{abstract}

Keywords: Disaster, Urban Flooding, Step Streets, Water Effect, CFD Method, Istanbul, FLOW 3D

\section{INTRODUCTION}

Most of the cities are under the threat of flash floods due to precipitation regime changes with global climate change. Infrastructure capacity may be insufficient during heavy rains and flash floods occur at weak points. Flood is one of the most common and deadly natural disasters with the earthquake. The floods disaster affects settlements all over the world and lead to catastrophic results with increasing effect of global warming too (Table 1). In a study conducted by the World Resources Institute (WRI) covering 164 countries, 15 countries were identified the most affected by river floods and flash floods each year. These countries also make up $80 \%$ of the world's population. In the study, India, Bangladesh and China are located at top three [1]. In the last decade of 20th century more than 100,000 people died and over 1.4billion affected due to the flood disaster.

Historical city Istanbul topography has many sloped areas where road formed as stepped streets with in many places. The existing infrastructure and the stepped streets that were not previously risky in the city now create a waterfall effect in heavy rain and reduce street safety. Due to high gradient of the stepped streets, the flow of water may put the lower level street at risk. Today, there are more than a hundred stepped streets in the settlement as by topography conditions such as Beyoğlu, Şişli and Üsküdar, with different type of stepped streets that form a short path in the transportation network in İstanbul. Excessive rains in recent years cause flash floods in Istanbul as in many cities. During precipitation, a waterfall effect may occur towards the street at the lower grade where the step streets are connected.

*Corresponding Author: halatoguzhan@gmail.com

Received: 16.10.2020 Published: 29.06.2021 
The geometry, drainage and material of the stair play an important role on this. The existing step streets which is formed past are rehabilitated according accessibility standards as possible.

Table.1: Overview of the ten river flood events with most people killed [2]

\begin{tabular}{|c|c|c|c|c|}
\hline Country & Date & Death & $\begin{array}{c}\text { Total } \\
\text { Effected }\end{array}$ & Description \\
\hline Venezuela & $\begin{array}{c}19 \\
\text { December } \\
1999\end{array}$ & 30.000 & 483.635 & $\begin{array}{l}\text { Flash and river floods and landslides around } \\
\text { Caracas and other areas }\end{array}$ \\
\hline Afghanistan & June 1988 & 6.345 & 166.831 & $\begin{array}{c}\text { Floods in Badakhsjan, Baghlan, Heart, Kabul, } \\
\text { Jouzjan, Samangan, Takhar provinces }\end{array}$ \\
\hline $\begin{array}{l}\text { China, P. } \\
\text { Rep. }\end{array}$ & June 1980 & 6.200 & 67.000 & Floods in Sichuan, Anhui, Hubei \\
\hline India & July 1978 & 3.800 & 32.000 .000 & Floods in north and northeast India \\
\hline $\begin{array}{l}\text { China, P. } \\
\text { Rep. }\end{array}$ & $\begin{array}{l}6 \text { August } \\
1998\end{array}$ & 3.656 & 238.973 .000 & $\begin{array}{l}\text { River floods combined with storms and } \\
\text { landslides in Hubei, Hunnan, Sichuan, Jiangxi, } \\
\text { Fujian, Guanxi Prov. }\end{array}$ \\
\hline
\end{tabular}

However, with the approach where user safety is at the forefront with climatic factors, it is important to make provisions against excessive rain to reduce the risks that may occur. In this context, determining the current situation constitutes the first stage. This study provides a different perspective for the studies on this subject.

\subsection{Literature Review}

Computer-based numerical modeling has been widely used by researchers in a vast range of problems related to hydraulic engineering. In 2014, a study carried out to observe free surface flows over hydraulic structures such as weirs, barrages, sluice gates, spillway etc. in rivers and natural channels [3]. Another study [4] was completed to compare the discharge and crest pressures from flow over an uncontrolled ogee crested spillway using physical and computational models. There is another research related numerical modelling of spillway flow in free drop and initially unknown discharge [5]. In addition to this problem geometry of the study area is also important. The effect of the geometry is studied on the free surface flow over a tunnel spillway using simulation generated by numerical modeling. It is important to minimize waves to avoid choking or overflow in design [6].

There are some studies related to hydraulic properties. In one of them researchers used the location of the water surface to calculate the capacity for the spillway by numerical modelling. They supported their studies with physical models. The capacity of spillways is important for the operation of dams and safety for floods [7]. In another study numerical model that capable of turbulent and complex free surface flows in open channels and complex embedded hydraulic structures such as groynes, bridge piers, boulders by not neglecting depth averaged and unsteady models was studied and improved [8]. The pressure distribution on stepped spillway using different techniques by numerical modelling are investigated [9]. The hydrodynamic behaviour of the side weir with two cycles which are effective hydraulic structures utilized commonly in irrigation, flood management, drainage and wastewater systems are presented using CFD method in numerical analysis [10]. In another study [11] the trapezoidal labyrinth shaped stepped spillway are investigated by numerical modelling. They evaluated the energy dissipation efficiency of the type of spillway using Computational Fluid Dynamics (CFD) techniques by FLOW-3D. The characteristics of flow energy dissipation over stepped spillways are analyzed for three different spillway heights using CFD techniques by FLOW-3D [12]. In another study [13] energy dissipation in simple stepped spillways is investigated by numerical models. Researchers studied air entrainment in skimming flow over the stepped spillways to investigate Mixture and volume of fluid (VOF) method's ability [14]. Then they compared numerical simulation results of hydraulic flow properties like free surface velocity components and air concentration in water with the 
experimental results. In another research, an experimental and numerical study carried out to compare flow depths over a stepped spillway using VOF method [15]. They also focused on a numerical procedure to detect free surface for the combined airwater flow. Apart from numerical modelling or using CFD method, there are different studies like investigation of free surface dynamics in several turbulent flows on stepped spillways using ultrasonic sensors [16]. The numerical modelling and estimating the flood risk which is often caused by rainfall overwhelming the local drainage capacity in urban areas, looks like related to our case, is studied [17]. They verified their model with laboratory experiments and real flood tracks in urban areas.

In general, the main difficulty of the problem is determining the flow transitions and discharge in spillways. In this study, the certain water height according to meteorological data is used for computational model. In addition to water height, the most important flow variables on the stepped spillways [11] which are the acceleration of gravity, the properties of fluid (dynamic viscosity, mass density etc.), the hydraulic properties of flow and the geometry of the spillway (step height, step length, number of steps, total height etc.) are considered. In this study the geometric shape of spillway changed into standard model stair and other model stairs in study area.

\section{MATERIAL AND METHODS}

In this study, two different stepped streets (Salı Pazarı Yokusu and Enli Yokusu) among six stepped streets related vertically with Meclis-i Mebusan Street (Fig 1, Fig 2) are examined in terms of flooding after heavy rains. The data was obtained through on-site observation. Physical properties such as stair length, width, slope, stair shape and railing are taken into consideration during the on-site examination. The stepped street as staircase models is analyzed with FLOW 3D software according to the selected flood height. In the numerical models examined by CFD method, the maximum speed zones occurring on the staircase during the flood were determined and the critical zones were specified. In this way, it is possible to comment on the impact assessment of stairs by considering water heights and speeds in critical areas.

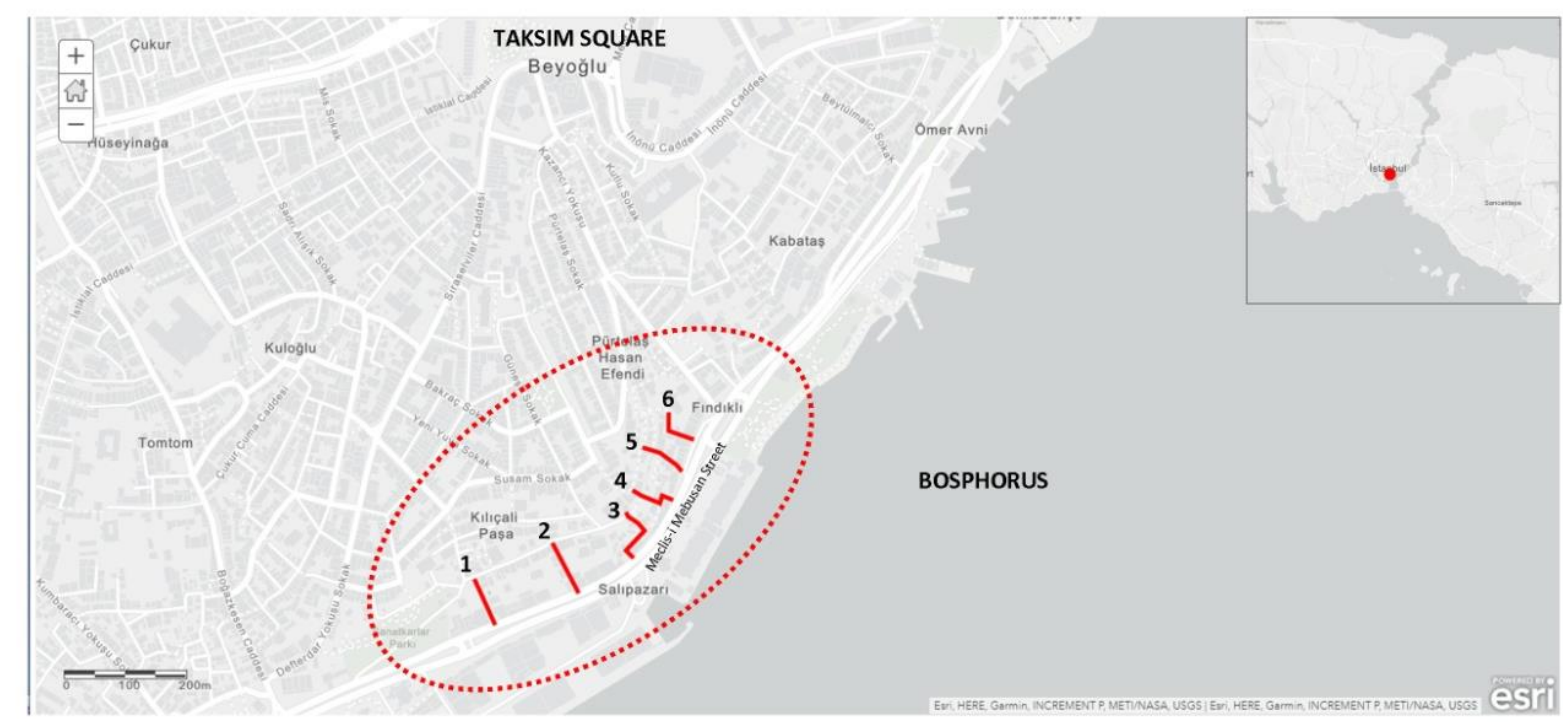

Figure 1. The stepped streets location map of case study area, İstanbul Beyoğlu District 1-Enli Yokuşu, 2-Salı Pazarı Yokuşu, 3-Fındıklı Yokuşu, 4-Tekke Yokuşu, 5-İsmail Dümbüllü Yokuşu, 6-Molla Bayırı Sokak (Location map prepared on ESRI arcGIS by Gül Yücel)

According to measurement and analysis results prepared by Turkey General Directorate of Meteorology, Annual Area Rainfall in the Marmara Region in 2017 was measured approximately $665 \mathrm{~mm}$. According 
to the 24-Hour Maximum Rainfall Map of the year 2017, the precipitation amount occurred in Istanbul is about $100 \mathrm{~mm}$ [18]. Depending to this information, the flood heights to be used in the analysis may vary according to the characteristics of the stepped stairs given in the Table 2.

As it's displayed at the table 2, the six of the stepped streets have different level differences, length, width, number of steps and step treads/risers. And in addition to table 2, they also have different geometric forms. Only the two of them are straight and the others are wiggly roads as seen at figure 1 . For the mathematical model, Enli Yokuşu and Salı Pazarı Yokuşu are chosen to be examined because of their straight forms.

Table.2 The stepped street samples in Istanbul Beyoğlu District

\begin{tabular}{|c|c|c|c|c|c|c|c|}
\hline & Name & $\begin{array}{l}\text { Width } \\
\text { (m) }\end{array}$ & $\begin{array}{l}\text { Number } \\
\text { of step }\end{array}$ & $\begin{array}{c}\text { Step } \\
\text { treads/risers } \\
(\mathrm{cm}) \\
\end{array}$ & $\begin{array}{c}\text { Level } \\
\text { difference }(\mathrm{m})\end{array}$ & $\begin{array}{l}\text { Length } \\
\text { (m) }\end{array}$ & $\begin{array}{c}\text { Number of } \\
\text { building }\end{array}$ \\
\hline 1 & Enli Yokuşu & 7,2 & 161 & $31 / 15-16$ & 30 & 80 & 6 \\
\hline 2 & Salı Pazarı Yokuşu & 3,2 & 182 & $32 / 17,5$ & 32 & 90 & 4 \\
\hline 3 & Findıklı Yokuşu & 2,6 & 206 & $32 / 19$ & 22 & 45 & 6 \\
\hline 4 & Tekke yokuşu & $2,4-2,9$ & 287 & $31 / 10$ & 50 & 125 & 13 \\
\hline 5 & $\begin{array}{c}\text { İsmail Dümbüllü } \\
\text { Yokuşu }\end{array}$ & 3,8 & 163 & $30 / 17,5$ & 33 & 106 & 10 \\
\hline 6 & Molla Bayırı Sokak & 2,8 & 153 & $27 / 15$ & 23 & 65 & 13 \\
\hline
\end{tabular}

As seen in Figure 2, unlike other stairs, Enli Yokuşu and Salı Pazarı Yokuşu extend in a linear direction between two streets. According to this condition, it is possible to compare these two stairs with the model created in standard sizes. In addition, although the number of steps and lengths of the stairs are relatively similar, the fact that the width of the stairs is quite different enables the effect of stair width to be observed in the analyzes. The stair geometries are close to the linear direction provides ease in the formation of the mesh structure during modeling and determining the boundary conditions.

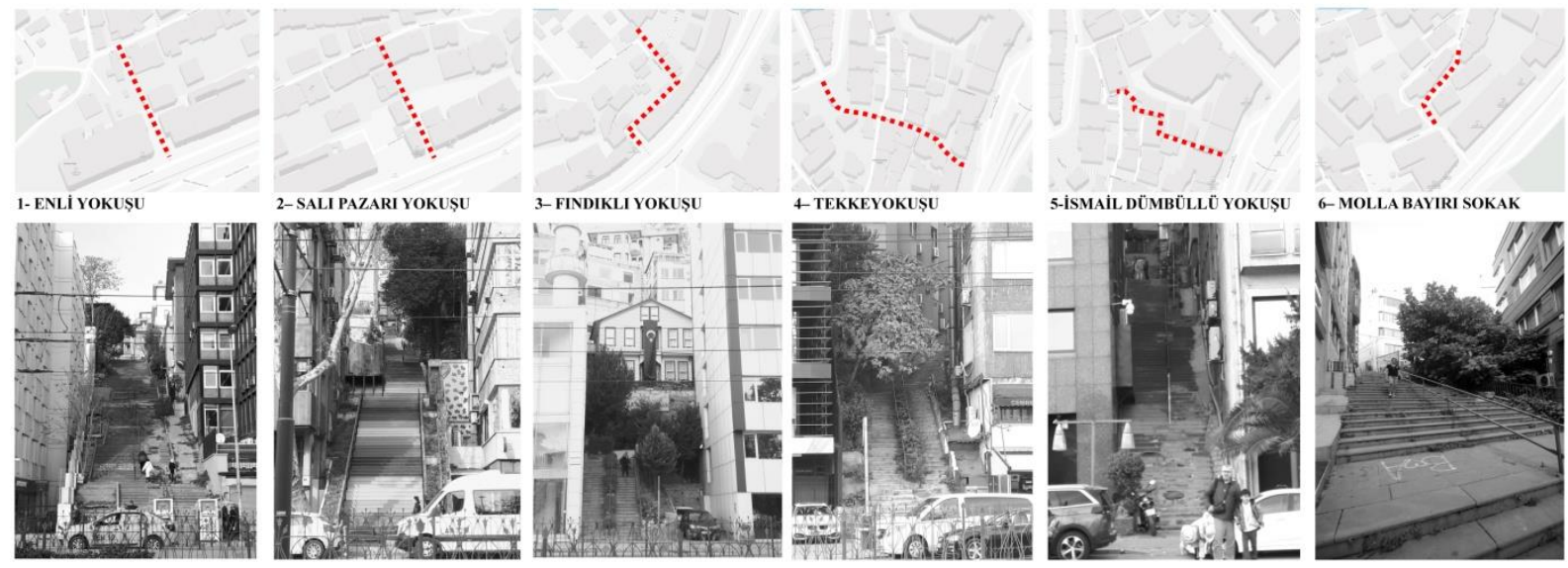

Figure 2. The geometric form of the stepped streets and general view from on Meclis-i Mebusan Street in Beyoğlu, Istanbul (The stepped streets geometric form showing on Google Map and photographs prepared by Gül Yücel)

\subsection{Software and Device Features}

FLOW 3D software is widely used in coastal and dam hydraulics to examine the free surface movement occurring especially in flood and spillway flows. With the help of CFD analysis, the hydraulic flow that can be examined can be analyzed in detail. As the structures considered in this study are similar to the design of stepped spillway flows in dams, they have been examined by taking into account similar design 
parameters. The generated numerical models were analyzed with the help of Windows 10 (64 bit) operating system, i5-8250U CPU and Intel ${ }^{\circledR}$ Core ${ }^{\mathrm{TM}}$ processor with $1.80 \mathrm{GHz}$ and $\mathrm{HP}$ computer with 8 GB of RAM memory.

\subsection{Numerical Model and Parameters}

In the analyzes, the standard model created in the dimensions specified in the instructions are compared with the model of the stair section in Enli Yokuşu and Salı Pazarı Yokuşu. The parameters are given in Table 3.

Table 3. Geometric parameters of stepped streets used in models

\begin{tabular}{|c|c|c|c|c|c|c|}
\hline & $\begin{array}{l}\text { Step Height } \\
(\mathrm{cm})\end{array}$ & $\begin{array}{l}\text { Step Width } \\
(\mathrm{cm})\end{array}$ & $\begin{array}{c}\text { Stair } \\
\text { Width (m) }\end{array}$ & $\begin{array}{c}\text { Number of } \\
\text { Landing }\end{array}$ & $\begin{array}{l}\text { Width of Landing } \\
\text { (m) }\end{array}$ & $\begin{array}{c}\text { Number of } \\
\text { Steps }\end{array}$ \\
\hline $\begin{array}{l}\text { Standard } \\
\text { Model }\end{array}$ & 15 & 30 & 2 & 14 & 2 & 195 \\
\hline $\begin{array}{l}\text { Enli } \\
\text { Yokuşu }\end{array}$ & 15.5 & 30 & 7.2 & 8 & $\begin{array}{c}1 \text { st } 2.6 \\
\text { Others } 2\end{array}$ & 161 \\
\hline $\begin{array}{l}\text { Salı Pazarı } \\
\text { Yokuşu }\end{array}$ & $17,5-18$ & 32 & 3,2 & 36 & $\begin{array}{c}\text { Changable } \\
\text { between } 80- \\
220 \mathrm{~cm}\end{array}$ & 182 \\
\hline
\end{tabular}

The model parameters for the stair sections that are taken into consideration were kept constant in order to make analysis and interpretation under the same conditions. In order to examine the free surface flow occurring in the sections of the stairs, parameters in Table 4 are used. The $g$ value is taken constant as 9.81 and material type is considered as solid and impermeable. Surface roughness parameter is taken as $0.05 \mathrm{~m}$ for each model considering the study [9] in the literature.

Table 4. Physical parameters of stepped streets, used in models

\begin{tabular}{|c|c|c|c|c|c|c|c|}
\hline & $\begin{array}{l}\text { Water } \\
\text { Height } \\
(\mathrm{cm})\end{array}$ & $\begin{array}{c}\text { Flow } \\
\text { Type/Model }\end{array}$ & $\begin{array}{l}\text { Turbulence } \\
\text { Length }\end{array}$ & $\begin{array}{c}\text { Density } \\
\text { and } \\
\text { Viscous } \\
\text { Properties }\end{array}$ & $\begin{array}{l}\text { Mesh } \\
\text { Size } \\
(\mathrm{m})\end{array}$ & $\begin{array}{l}\text { Number of } \\
\text { Meshes }\end{array}$ & $\begin{array}{l}\text { Pressure } \\
\text { Type }\end{array}$ \\
\hline $\begin{array}{l}\text { Standard } \\
\text { Model }\end{array}$ & 30 & $\begin{array}{l}\text { Viscous and } \\
\text { turbulent / } \\
\text { RNG model }\end{array}$ & $\begin{array}{l}\text { Dynamically } \\
\text { computed }\end{array}$ & $\begin{array}{c}\text { Same as } \\
\text { water at } \\
20{ }^{\circ} \mathrm{C}\end{array}$ & 0.1 & 6092726 & Hydrostatic \\
\hline $\begin{array}{l}\text { Enli } \\
\text { Yokuşu }\end{array}$ & 30 & $\begin{array}{l}\text { Viscous and } \\
\text { turbulent / } \\
\text { RNG model }\end{array}$ & $\begin{array}{l}\text { Dynamically } \\
\text { computed }\end{array}$ & $\begin{array}{c}\text { Same as } \\
\text { water at } \\
20{ }^{\circ} \mathrm{C}\end{array}$ & 0.1 & 12630396 & Hydrostatic \\
\hline $\begin{array}{l}\text { Salı Pazarı } \\
\text { Yokuşu }\end{array}$ & 30 & $\begin{array}{l}\text { Viscous and } \\
\text { turbulent / } \\
\text { RNG model }\end{array}$ & $\begin{array}{l}\text { Dynamically } \\
\text { computed }\end{array}$ & $\begin{array}{c}\text { Same as } \\
\text { water at } \\
20^{\circ} \mathrm{C}\end{array}$ & 0.1 & 8754050 & Hydrostatic \\
\hline
\end{tabular}

\section{THE RESEARCH FINDINGS AND DISCUSSION}

With this study, as a according to result of the analysis, the flow of rainwater flowing on three different cross sections are examined. In all three models, flowing water are observed to reach high speeds at certain points throughout the section. As the stairs approach the end, it is seen that the flow velocity leaves the section by making leaps due to the destructive effect of the steps. It is observed that the water height decreases at some points on the model sections depending on the section width.

Based on the analyzes made on the standard model, the highest horizontal flow velocity values taken from the fluid probes in the model. As can be seen from the Figure 3, fluid velocity reach nearly $4 \mathrm{~m} / \mathrm{s}$ 
while the average value of it is $2.5 \mathrm{~m} / \mathrm{s}$. It is observed that the flow rate increases in the area where the 8th Landing is located on the staircase section.

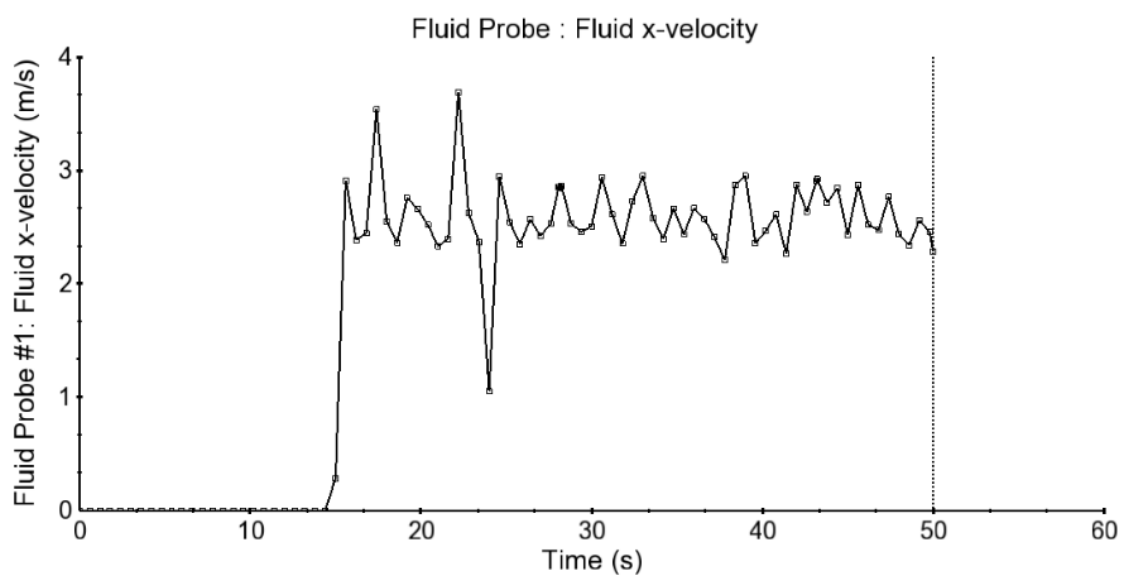

Figure 3. Horizontal flow velocity values at fluid probe of the standard model $(\mathrm{m} / \mathrm{s})$

The visual of the instantaneous time step showing the horizontal flow rate change on the cross section of the standard model is given in Figure 4. As can be seen from the figure, the flow rates are close to each other across the section. At the end of the stairs, it leaves the section with small splashing. It can be said that the reason for the flow rates along the staircase to be close to each other is that the staircase section, step heights, stair and step widths and landing lengths are constant and uniform throughout the stair cross-section.

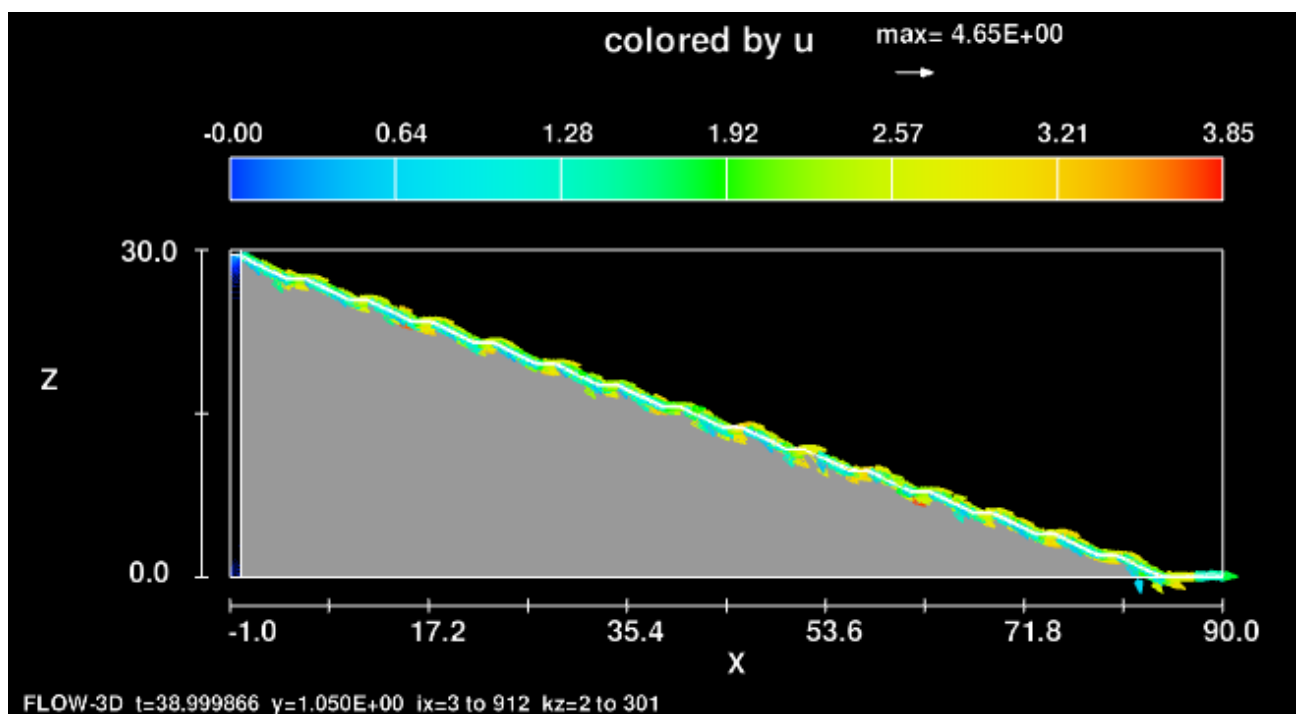

Figure 4. Change of horizontal flow rate on standard model section

The 3D image of the standard model analysis result is given in Figure 5. As can be seen in the figure, it is understood that the water height does not change along the staircase and the flow rate is at a similar level throughout the section. 


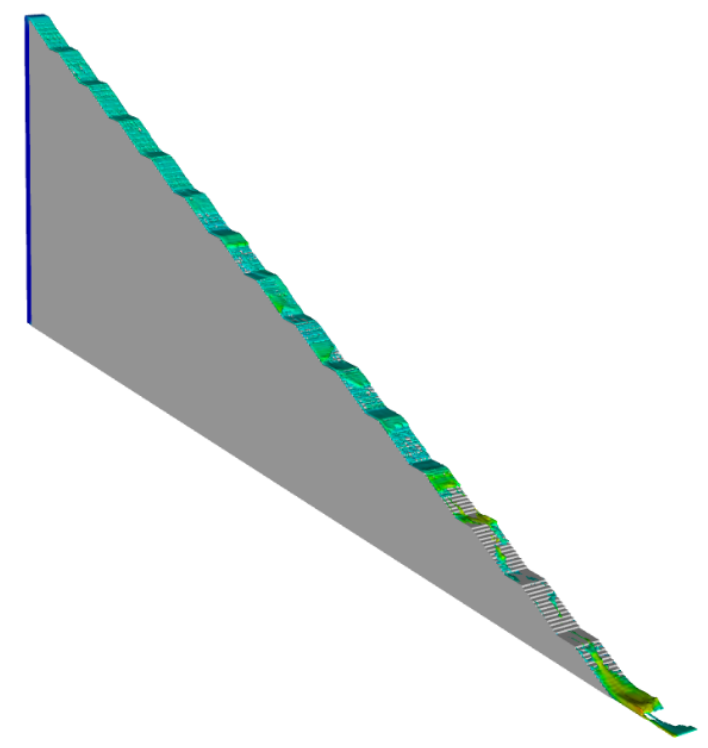

Velocity Selected $(\mathrm{m} / \mathrm{s})$

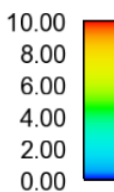

Figure 5. 3D view of the standard model analysis result

The highest horizontal flow velocity values taken from the fluid probes based on the analyzes made on Enli Yokuşu is given in Figure 6. As can be seen from the graph, it can be said that the average flow velocity in the staircase section is around $3 \mathrm{~m} / \mathrm{s}$. It is observed that the flow rate increases in the region where the 7th and 10th landings are located on the staircase section.

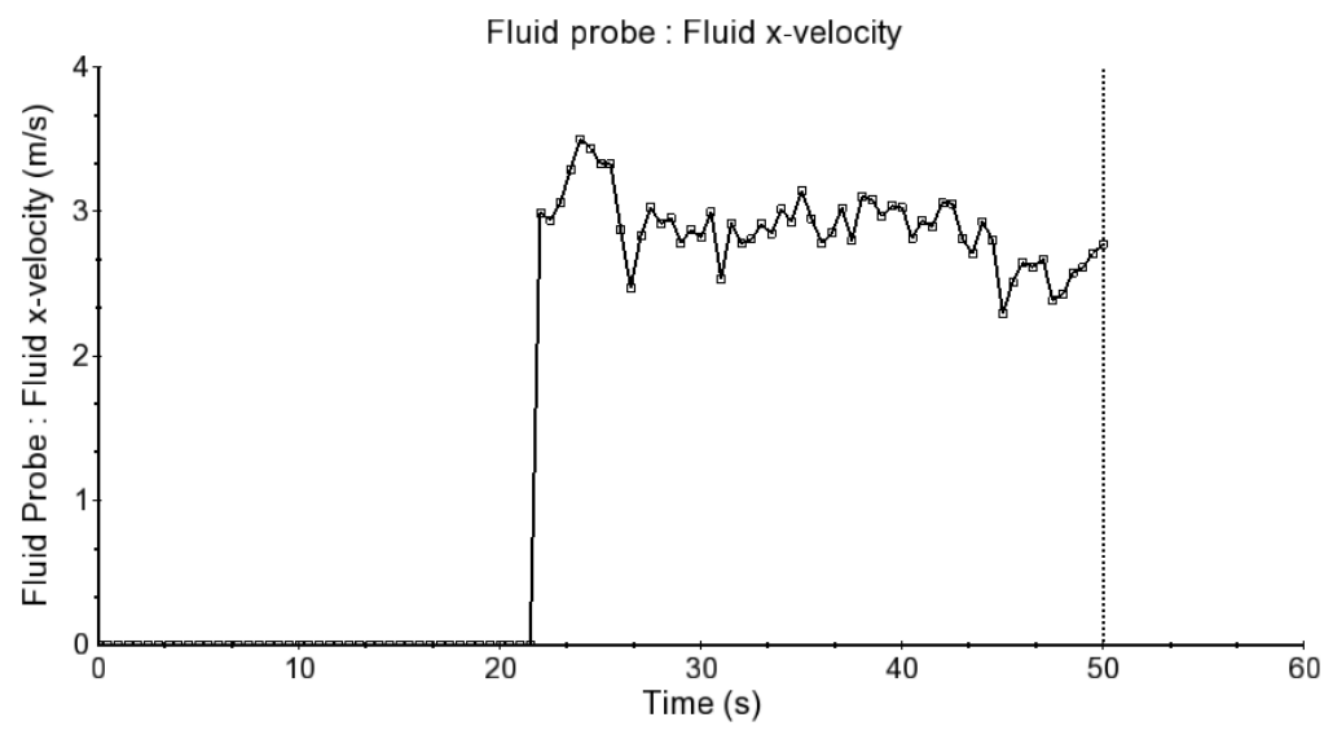

Figure 6. Horizontal flow velocity values at fluid probe of the Enli Yokusu model $(\mathrm{m} / \mathrm{s})$

The visual of the instantaneous time step showing the horizontal flow rate change on the section of Enli Yokuşu is given in Figure 7. It can be seen that the highest velocity seen in the horizontal flow rate change displayed in the 44th time step appears after a distance of approximately 40 meters. The flow, which differs from the standard model due to the staircase geometry, leaves the staircase section with lower flow rates. 


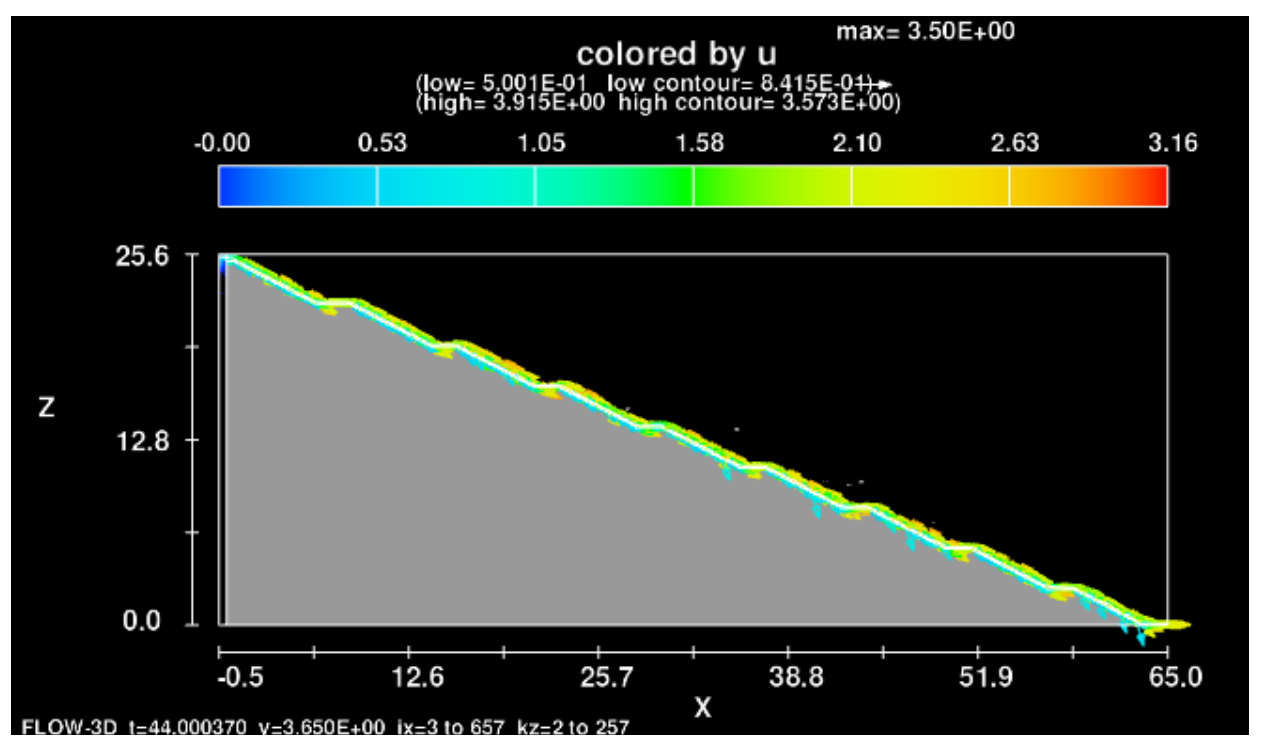

Figure 7. Change of horizontal flow rate on the Enli Yokuşu model section

The 3D image of the Enli Yokuşu analysis result is given in Figure 8. It is seen that the height of the water does not spread uniformly due to the width of the stairs. Accordingly, while the water height decreases in some regions on the section, it also increases in some regions. In relation to the horizontal flow velocity values given in Figure 6, it is seen that the flow velocity on the section remains at an average of $3 \mathrm{~m} / \mathrm{s}$.
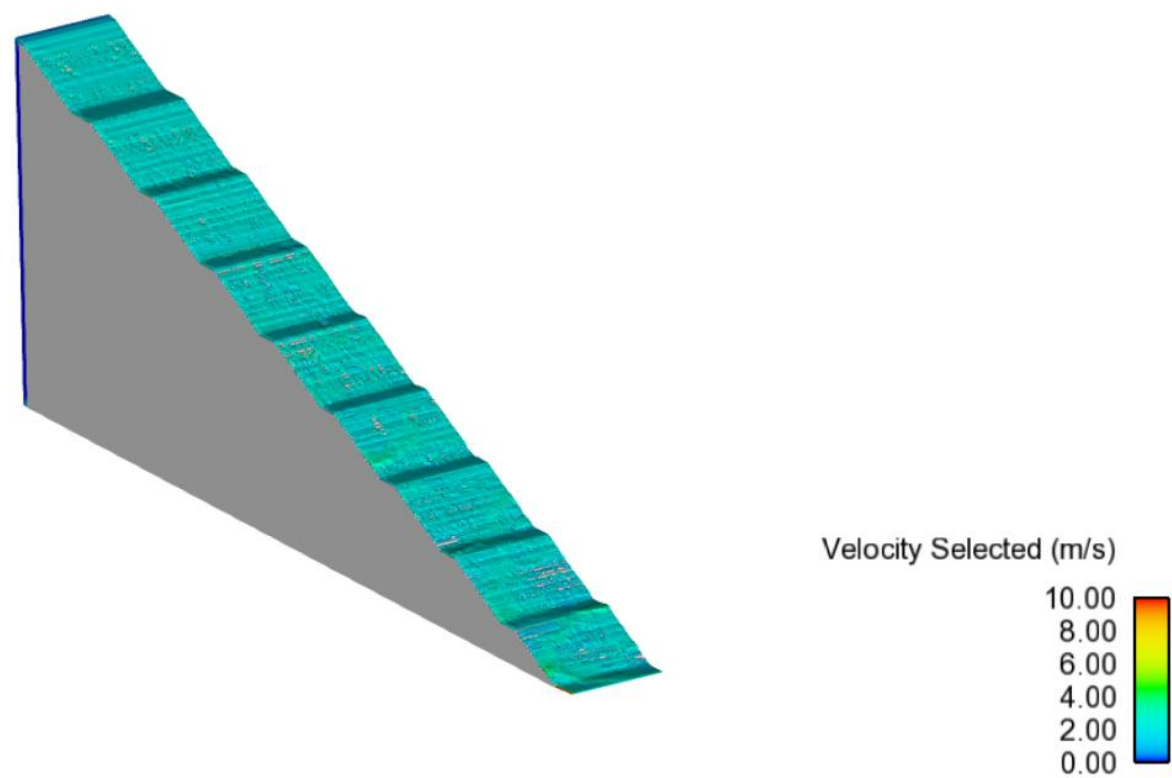

Figure 8. 3D view of Enli Yokuşu analysis result

Based on the analyzes carried out on Salı Pazarı Yokuşu, horizontal flow velocity graph taken from fluid probes is given in Figure 9. As can be seen from the graph, it can be said that the average flow velocity in the staircase section is around $2 \mathrm{~m} / \mathrm{s}$. It is observed that the flow rate increases in the region where the 4th and 7 th landings are located on the staircase section. 


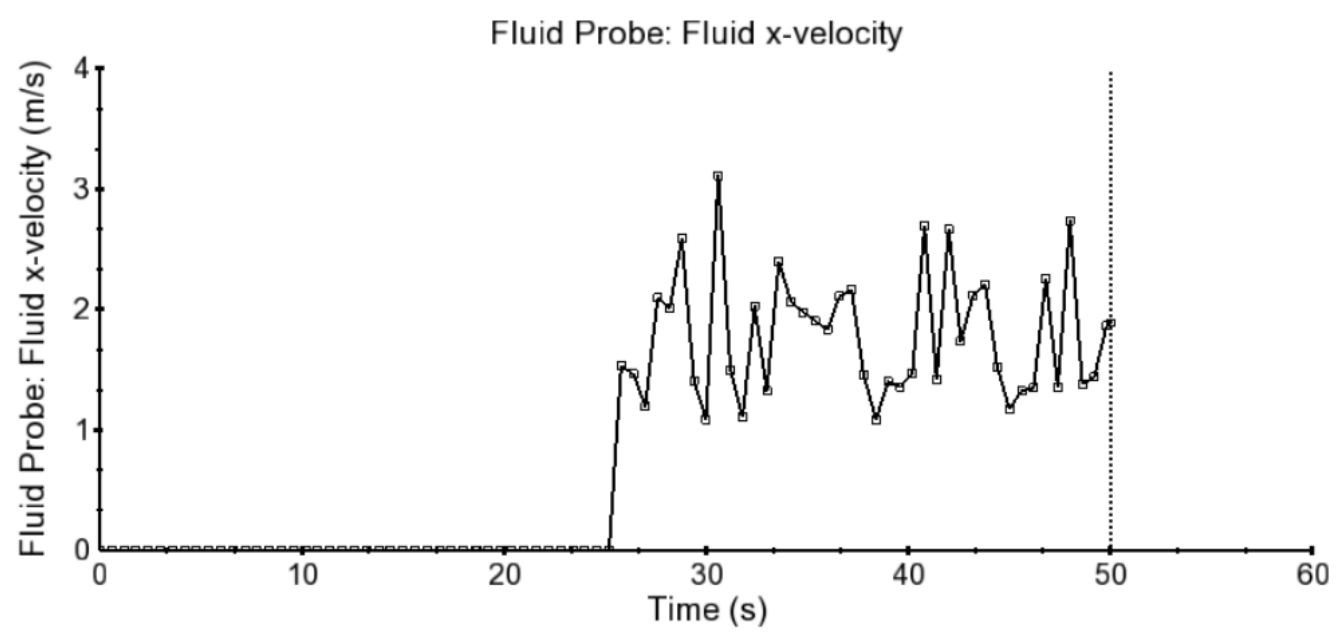

Figure 9. Horizontal flow velocity values at fluid probe of the Salı Pazarı Yokuşu model (m/s)

The visual of the instantaneous time step showing the horizontal flow rate change on the section of Sal1 Pazarı Yokuşu is given in Figure 10. The highest velocity seen in the horizontal flow rate change displayed in the 42 nd time step appears to occur at a distance of approximately 60 meters and about 3 $\mathrm{m} / \mathrm{s}$. Unlike other models, the flow trend varies and speed changes between different levels due to the irregular stair geometry. Again, unlike other models, it is seen that the region where high speeds are concentrated occurs in a section closer to the end of the stairs.

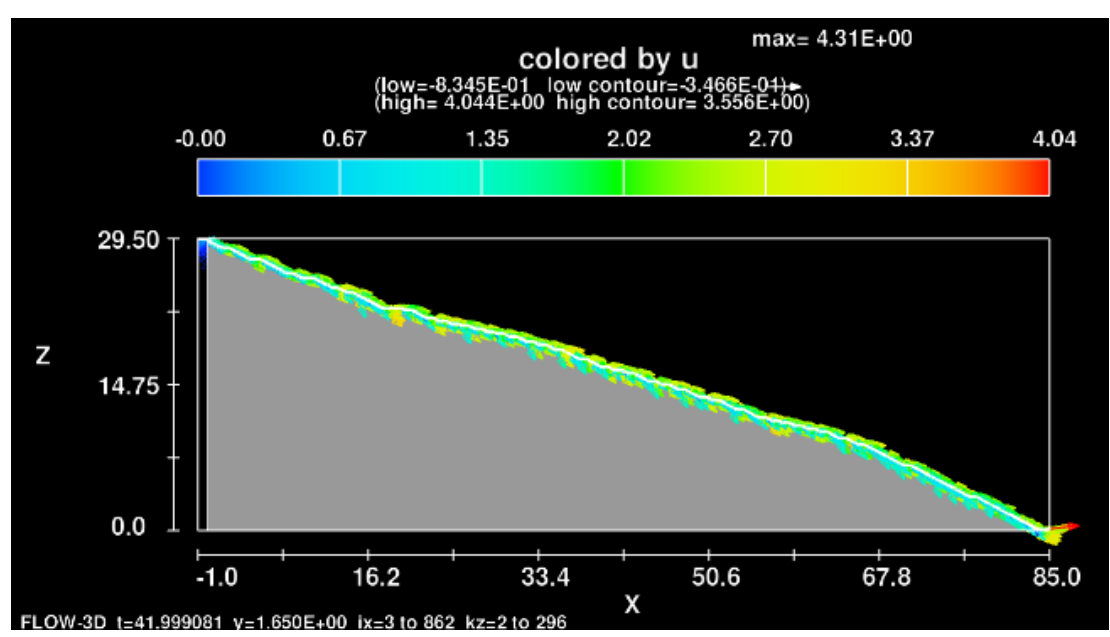

Figure 10. Change of horizontal flow rate on Salı Pazarı Yokuşu model section

The 3D image of the Salı Pazarı Yokuşu analysis result is given in Figure 11. It is seen that the water height does not spread uniformly through the effect of the staircase geometry throughout the section. Accordingly, while the water height decreases in some regions on the section, it also increases in some regions. As at some points on the section, it can be seen that the flow rate increases slightly as it approaches the end of the stairs. 

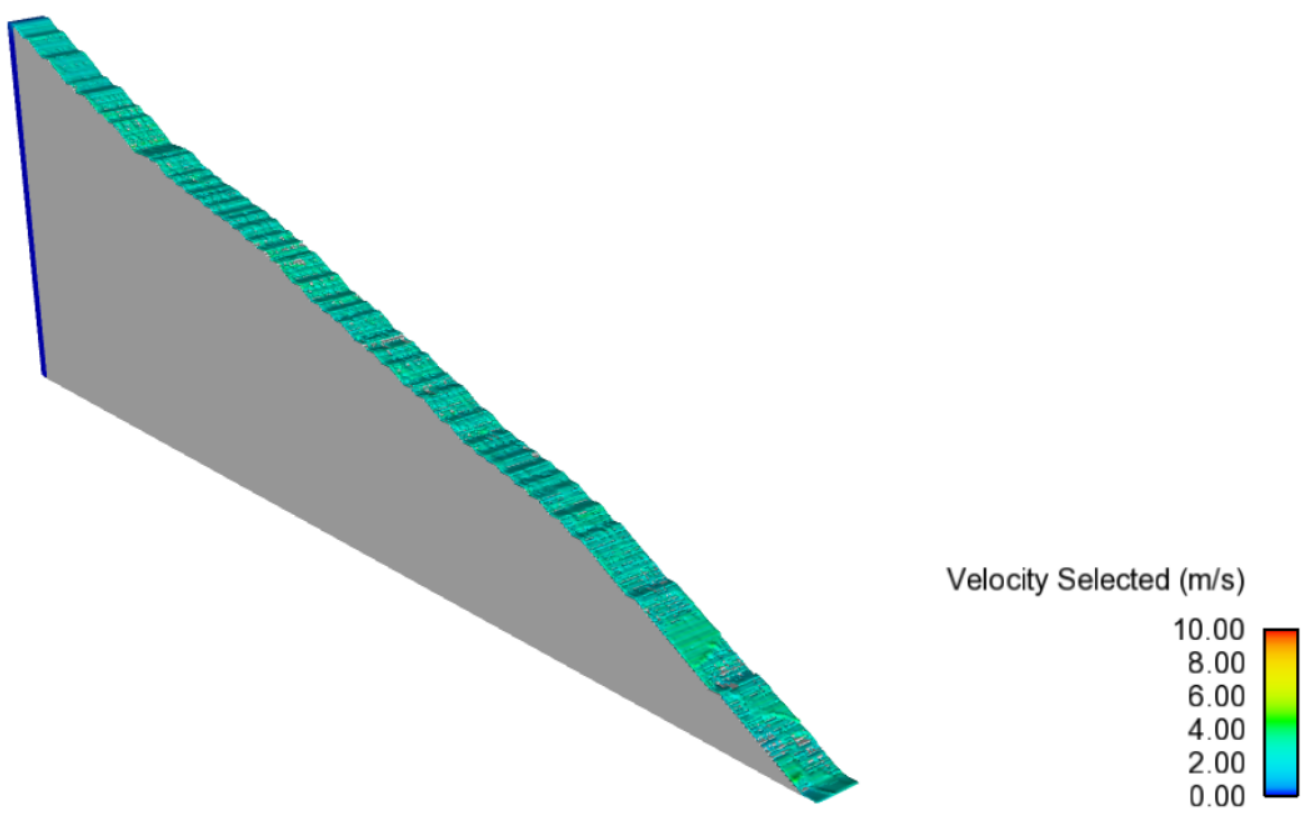

Figure 11. 3D view of Salı Pazarı Yokuşu analysis result

Turkish Standards TS 12576 (Urban roads - Structural preventive and sign design criteria on accessilibilty in sidewalks and pedestrian crossings), which came into force in 2012, includes the design rules of structural measures and markings for all pedestrians, including those with reduced mobility, can safely and comfortably use sidewalks, pedestrian roads, crossings and intersections on urban roads. It is obligatory to comply with the provisions of this Communiqué for purchases of goods or services as well as those who do or perform construction works on the subjects included by TS 12576. In the stair treads and color selection title (1.3.9.1), it is mentioned that there is a protective non-slip strip $2.5 \mathrm{~cm}$ wide from the end of the step, the protective material must be mounted so that it does not fall off, does not protrude and is flat with the step surface [19]. Also in 1.3.9.2.2. title it's mentioned that the stairs should be at least $180 \mathrm{~cm}$ from the handrail to the handrail on the stairs. Grooves should be made on the sides of the stairs.

\section{CONCLUSION}

Disaster statistics show that flood is the second most important disaster after the earthquake in Turkey. Flash floods due to changes in precipitation regime are frequently occurred. The stepped streets can be also affected the safety of the users walking on them and the surrounding buildings with the effect of waterfall created after excessive rainfall. The safety condition of pedestrian way at lower street may affect due to the flood on stepped streets. The stepped streets are a shortcut of some sort which is related with city topography and its history tightly. Existing stepped streets should be checked for meet the related standards for achieving its safety in terms of natural disaster. The most important issue for flooding is to reduce the fluid speed. As the slope and elevation increases, the risk of flooding increases. Infrastructure works should be given importance in city floods, the sizes and number of gratings should be increased. Flood forecasting and early warning systems should be developed. Flood protection and action plans should be prepared. Some other precautions should be taken against the flash floods. These are;

Drainage system:

Drainage system should be resistant to abrasion and breakage. There should be no risk of stumble in the drainage system. It is important to integrate the ducts with the floor material in order to ensure visual 
quality. The grating cover design should be meet the accessibility standards, for safety using. Continuous drainage system and uninterrupted duct volumes are also important technical issues.

Step design to control flow rate:

In the numerical model, free surface flows that can occur on different staircase types with variable step and landing properties are investigated. Based on the analysis results, it is understood that the flow on the staircase sections varies depending on the staircase geometry. In the standard model created in standard sizes, a relatively uniform flow was observed at an average of $2.5 \mathrm{~m} / \mathrm{s}$ across the section. In the Enli Yokuşu model, where the width of the stairs is bigger, it was determined that the flow accelerated to reach $3 \mathrm{~m} / \mathrm{s}$, but the water height did not spread uniformly over the staircase section. Accordingly, the regions where high flow rates concentrated on the staircases are differed. In the Salı Pazarı Yokuşu model, which has a more geometrically irregular structure compared to other models, flow rates are observed at different levels as the flow became more turbulent. In this model, as a result of geometrical irregularity, the regions where flow velocities of an average of $3 \mathrm{~m} / \mathrm{s}$ are concentrated, unlike other models, are observed in the landing and step areas near the end of the stairs.

\section{Material selection:}

One of the most important factors is that the materials for the steps forming the stepped streets are impermeable. Both stairs chosen for the research are impermeable. It will not be enough if the steps are only non-slip against the flash flood, in such a case it is also important to have a handrail that can be grabbed.

Based on this study aimed at evaluating the structure of the Enli Yokuşu and Salı Pazarı Yokuşu Street against flood disaster, it will be useful to examine the other step streets having 100 and above steps in the city. In addition, structural applications as well as the precautions to be taken must be examined for each stepped street, thus minimizing material losses.

Flood control for stepped streets is an interdisciplinary field within the scope of disaster safety. For cities' resilience, solutions on this type of street should be developed interdisciplinary as engineering, urban planning, landscape architecture, architecture, material sciences and local administrations. Future research in this field is searching for other parameters which affect water flow on different stepped street typologies.

\section{CONFLICT OF INTEREST}

The authors stated that there are no conflicts of interest regarding the publication of this article.

\section{REFERENCES}

[1] https://www.wri.org/blog/2015/03/world-s-15-countries-most-people-exposed-river-floods (last accessed: 27.07.2020)

[2] Jonkman SN. Global Perspectives on Loss of Human Life Caused by Floods, Natural Hazards, $2005 ; 34,151-175$.

[3] Nguyen VT. 3D Numerical Simulation of Free Surface Flows Over Hydraulic Structures In Natural Channels And Rivers', Applied Mathematical Modelling, 2014; 39(20), 6285-6306. 
[4] Savage BM, Johnson MC, Flow Over Ogee Spillway: Physical and Numerical Model Case Study, Journal of Hydraulic Engineering, 2001; 127 (8).

[5] Yakun G, Xianyun W, Chigong W, Duo F. Numerical Modelling of Spillway Flow with Free Drop and Initially Unknown Discharge, Journal of Hydraulic Research, 1998; 36 (5), 785-801.

[6] Song CCS, Zhou F. Simulation of Free Surface Flow Over Spillway, Journal of Hydraulic Engineering, 1999; 125 (9).

[7] Olsen NRB, Kjellesvig HM. Three-Dimensional Numerical Flow Modelling for Estimation of Spillway Capacity, Journal of Hydraulic Research, 1998; 36 (5), 775-784.

[8] Kang S, Sotiropoulos F. Numerical Modeling of 3D Turbulent Free Surface Flow In Natural Waterways, Advances in Water Resources, 2012; 40, 23-36.

[9] Husain SM, Muhammed JR, Karunarathna HU, Reeve DE. Investigation of Pressure Variations Over Stepped Spillways using Smooth Particle Hydrodynamics 2014, Advances in Water Resources, 66, 52-69.

[10] Aydin MC, Emiroglu ME. Numerical Analysis of Subcritical Flow Over Two-Cycle Trapezoidal Labyrinth Side Weir, Flow Measurement and Instrumentation, 2016; 48, 20-28.

[11] Ghaderi A, Abbasi S, Abraham J, Azamathulla HM. Efficiency of Trapezoidal Labyrinth Shaped Stepped Spillways, Flow Measurement and Instrumentation, 2020; 72.

[12] Irzooki RH, Mohammed R.J, Ameen SA. Computational Fluid Dynamics Modeling of Flow over Stepped Spillway, Tikrit Journal of Engineering Sciences, 2016; 23 (3),1-11.

[13] Rad NI, Teimouri M. An Investigation of Flow Energy Dissipation in Simple Stepped Spillways by Numerical Model, European Journal of Scientific Research, 2010; 47(4), 544-553.

[14] Eghbalzadeh A, Javan M. Comparison of Mixture and VOF Models for Numerical Simulation Of Air-Entrainment In Skimming Flow Over Stepped Spillways', Procedia Engineering, 2012; 28, 657-660.

[15] Lopes P, Leandro J, Carvalho RF. Numerical Procedure for Free-Surface Detection Using A Volume-of-Fluid Model, Journal of Hydro-Environment Research, 2018; 21, 43-51.

[16] Zhang G, Valero D, Bung DB, Chanson H. On The Estimation of Free-Surface Turbulence using Ultrasonic Sensors, Flow Measurement and Instrumentation, 2018; 60, 171-184.

[17] Xia J, Falconer RA, Lin B, Tan G. Modelling Flash Flood Risk In Urban Areas, Proceedings of the Institution of Civil Engineers: Water Management, 2011; 164 (6), 267-282.

[18] Orman ve Su İşleri Bakanlığı (2018) Araştırma Dairesi Başkanlığı Meteorolojik Afetler Şube Müdürlüğü, Meteorolojik Karakterli Doğal Afetler 2017 Yılı Değerlendirmesi, https://www.mgm.gov.tr/FILES/genel/kitaplar/2017MeteorolojikAfetlerDegerlendirmesi.pdf (last accessed : 27.07.2020)

[19] TS 12576. (2012) TS 12576. Şehir içi yollar - Kaldırım ve yaya geçitlerinde ulaşılabilirlik için yapısal önlemler ve işaretlemelerin tasarım kuralları, Ankara, Türk Standartları Enstitüsü. http://www.erisebilirim.com/Images/ts-12576.pdf (last accessed: 27.07.2020). 